\title{
Impact of integrated use of enriched compost, biochar, humic acid and Alcaligenes sp. AZ9 on maize productivity and soil biological attributes in natural field conditions
}

\author{
Azhar Hussain, ${ }^{1}$ Maqshoof Ahmad, ${ }^{1}$ Muhammad Zahid Mumtaz, ${ }^{2}$ Farheen Nazli, ${ }^{3}$ \\ Muhammad Aslam Farooqi, ${ }^{4}$ Imran Khalid, ${ }^{5}$ Zafar Iqbal, ${ }^{1}$ Hadeeqa Arshad 6 \\ ${ }^{1}$ Department of Soil Science, University College of Agriculture and Environmental Sciences, the Islamia \\ University of Bahawalpur; ${ }^{2}$ Institute of Molecular Biology and Biotechnology, The University of Lahore; \\ ${ }^{3}$ Pesticide Quality Control Laboratory, Bahawalpur; ${ }^{4}$ Department of Entomology, University College of \\ Agriculture and Environmental Sciences, the Islamia University of Bahawalpur; ${ }^{5}$ University College of \\ Agriculture and Environmental Sciences, The Islamia University of Bahawalpur; ${ }^{6}$ Pakistan Institute for \\ Engineering and Applied Sciences (PIEAS), Islamabad, Pakistan
}

\begin{abstract}
Organic amendments improve the soil quality and plant productivity as well as help in the establishment of introduced bacteria. The present study was conducted to evaluate the interactive
\end{abstract}

\footnotetext{
Correspondence: Azhar Hussain, Department of Soil Science, University College of Agriculture and Environmental Sciences, The Islamia University of Bahawalpur, Bahawalpur-63100, Punjab, Pakistan.

Tel.: +92.321.6814625. E-mail: azharhaseen@gmail.com
}

Key words: Biochar; compost; soil organic carbon; organic matter; plant growth promoting rhizobacteria.

Acknowledgements: we acknowledge the Department of Soil Science, University College of Agriculture and Environmental Sciences, The Islamia University of Bahawalpur, Pakistan, for providing research facilities. We are also thankful to the Dr. Muhammad Naveed (Assistant Professor), Environmental Sciences Laboratory at Institute of Soil and Environmental Sciences (ISES), University of Agriculture Faisalabad, Pakistan for the provision of biochar and rock phosphate enriched compost.

Funding: this project is funded by the Higher Education Commission (HEC) of Pakistan under Start-up Research Grant Program (SRGP).

Contributions: AH, MA, planned the experiment; AH, MA, ZI, conducted the experiment; AH, MZM, IK, MAF prepared initial and final draft; HA, FN reviewed and formatted manuscript.

Conflict of interests: the authors declare no potential conflict of interests.

Received for publication: 25 February 2019

Revision received: 12 April 2019.

Accepted for publication: 16 April 2019.

(C) Copyright A. Hussain et al., 2019

Licensee PAGEPress, Italy

Italian Journal of Agronomy 2019; 14:1413

doi:10.4081/ija.2019.1413

This article is distributed under the terms of the Creative Commons Attribution Noncommercial License (by-nc 4.0) which permits any noncommercial use, distribution, and reproduction in any medium, provided the original author(s) and source are credited. impact of organic amendments and plant growth promoting rhizobacteria strain Alcaligenes sp. AZ9 to improve maize productivity and soil quality. organic amendments including rock phosphate enriched compost (RPEC), biochar, and humic acid were applied in soil along with and without Alcaligenes sp. AZ9. The results revealed that the sole application of organic amendments along with Alcaligenes sp. AZ9 showed increase in growth and grain yield of maize. However, a combined application of organic amendments (RPEC, biochar, and humic acid) along with Alcaligenes sp. AZ9 showed maximum increase in plant height up to $14 \%$, shoot dry biomass up to $30 \%, 1000$-grains weight up to $10 \%$, grain yield up to $31 \%$, stover yield up to $34 \%$, and potassium (K) concentration in grains up to $12 \%$ as compared to absolute control. The increase in nitrogen $(\mathrm{N})$ and phosphorus $(\mathrm{P})$ concentration in grains was non-significant over control. This treatment also improved soil biological attributes in terms of the bacterial population up to $60 \%$, microbial biomass carbon up to $22 \%$, soil organic carbon up to $29 \%$, and saturation percentage of soil up to $14 \%$ as compared to control. It can be concluded that the application of organic amendments improved establishment of introduced bacteria, which could be effective in improving maize growth and yield as well as soil health.

\section{Introduction}

The arid and semi-arid regions of Bahawalpur, Pakistan are categorised as poor soil without adequate soil nutrient replenishment and contain a negligible amount of organic matter. The limited availability of resources to farmers and droughts are the main causes of low agricultural production (Arshad et al., 2007). The declining soil fertility coupled with arid environment increases the crop failure threats. Extensive use of chemical fertilisers is common which leads to serious environmental and food quality degradation as well as increasing cost of fertilisers (Lal et al., 2010). Globally, sustainable crop production practices with renewable resources are getting attraction. Use of organic wastes is considered a valuable resource to improve soil fertility, agriculture production with less dependence on chemical fertilisers and helps in recycling of solid wastes (Randolph et al., 2017). Soil organic carbon is declining in various agroecology due to soil oxidation and erosion (Chappell et al., 2019). Application of organic amendments in the form of manures 
originated from plants, animals, poultry, humans, rock phosphate enriched compost (RPEC), and vermicompost are useful to control the depletion of soil organic carbon (SOC) (Mahmoodabadi et al., 2013). Composting technology successfully utilises and transforms organic wastes into a value-added product, suitable for agricultural productivity (Onwosi et al., 2017). There is a need to improve organic matter of soil of arid and semi-arid regions through recycling organic matter and other bioresources (Alluvione et al., 2013). Rock-phosphorus enriched compost is more advantageous than chemical fertiliser as organically bounded $\mathrm{P}$ is less susceptible to sorption and precipitations and it also stimulates microbial activity by addition of carbon (Malik et al., 2012). It improves soil quality and plant nutrition by improving soil properties and soil enzymes through activities of microflora (Caravaca et al., 2005).

There are abundant microorganisms flourishing in plant rhizosphere known as plant growth promoting rhizobacteria (PGPR). They influence plant growth and development positively through conferring one or more growth promoting characteristic (Shahzad et al., 2013). A number of PGPR possess symbiosis and exert their beneficial effects on plant growth and enhance plant resistance to environmental stresses (Vessey and Buss, 2003). They can also help to alleviate stress in plants grown in the arid and semi-arid environments through adopting a number of mechanisms to increase the plant growth, grain yield, and quality (Ahmad et al., 2013). These mechanisms are atmospheric $\mathrm{N}$ fixation, $\mathrm{P}, \mathrm{K}$, and $\mathrm{Zn}$ solubilisation, enzymatic activities viz. catalase, protease, amylase, and chitinase activities, production of volatile organic compounds, siderophores, phytohormones viz. indole acetic acid (IAA) and pathogen suppression by producing antibiotics (Ahemad and Kibret, 2014; Mittal et al., 2017). PGPR secreted numerous acid metabolites viz. citric, lactic, gluconic, 5-keto-gluconic, oxalic, succinic, tartaric and propionic acids having ability to convert non-labile form of minerals in to labile form (Chen et al., 2006; Alori et al., 2017). So, their use along with organic amendments have been emerging as a useful tool to improve nutrients availability and soil quality which help to increase plant growth and yield (Khan et al., 2015).

Application of organic amendments increases soil fertility through improving its physical, chemical, and biological properties (Chen et al., 2018). Soil biological activities determined the yield potential of a specific soil. Application of PGPR and organic amendments significantly improved soil biological properties viz. SOC, microbial biomass carbon (MBC), and useful microbial population which are important for sustainable yield production (Bertrand et al., 2015). SOC content can be enhanced in soil through organic inputs by plants, animals and microbial residues like manure, peat, compost, biochar, and slurry which help in restoring soil fertility and suppression of soil borne pathogens (Tejada et al., 2009; Scotti et al., 2015). Combined use of PGPR and organic amendments reduced fertiliser requirement (Moharana et al., 2018). Individual role of PGPR and organic amendments are well known in literature however, information about their combined use is limited. The combined use of these organic sources could be an effective approach to improve crop growth, yield, and soil health even under stress conditions. Keeping in view the above facts, the combined application of PGPR in terms of Alcaligenes sp. AZ9 and organic amendment were evaluated to improve the growth and yield of maize, nutrient concentration in grains and soil biological attributes.

\section{Materials and methods}

\section{Collection of organic amendments and Alcaligenes sp. AZ9}

The organic amendments viz. biochar, RPEC and humic acid were evaluated in the current study. Biochar was prepared from maize straw as described in Hussain et al. (unpublished). The RPEC was obtained from the Environmental Sciences Laboratory, Institute of Soil and Environmental Sciences (ISES), University of Agriculture Faisalabad (UAF), Pakistan (Ditta et al., 2015). The $50 \%$ humic acid (Warble Pvt. Ltd. Pakistan) was purchased from local market of Bahawalpur, Punjab, Pakistan. The chemical analysis of biochar and RPEC were performed and given in Hussain et al. (unpublished). The plant growth promoting bacterial strain Alcaligenes sp. AZ9 (Accession \# KU494828) was also obtained from the Environmental Sciences Laboratory, ISES, UAF, Pakistan (Hussain et al., 2015). The Alcaligenes sp. AZ9 was positive for phosphorus $(\mathrm{P})$ solubilisation, zinc $(\mathrm{Zn})$ solubilisation, 1-aminocyclopropane-1-carboxylate (ACC) deaminase activity and IAA and siderophores production (Hussain et al., unpublished).

\section{Field experiments}

A field experiment was conducted in the Farm Area of University College of Agriculture and Environmental Sciences (UCA\&ES), The Islamia University of Bahawalpur (IUB), Punjab, Pakistan with the aim to evaluate the combined application of biochar, RPEC, humic acid and Alcaligenes sp. AZ9 to improve growth, yield and quality of maize. Alcaligenes sp. AZ9 was grown in nutrient broth for $24 \mathrm{~h}$ and inoculum containing approximately $10^{11}$ cell mL $\mathrm{mL}^{-1}$ (Mumtaz et al., 2018) was coated on RPEC. Soil of the current field study was sandy loam having $35.5 \%$ saturation percentage, $7.93 \mathrm{pH}, 1.39 \mathrm{dS} \mathrm{m}^{-1}$ electrical conductivity (EC), $0.31 \%$ SOC, $0.52 \%$ organic matter, $0.05 \%$ total $\mathrm{N}, 0.05 \mathrm{mg} \mathrm{kg}^{-1}$ available $\mathrm{P}$, and $86.0 \mathrm{mg} \mathrm{kg}^{-1}$ extractable $\mathrm{K}$. Maize variety (Pioneer 31R88) was used as test crops in the present experiment. A set of 10 treatments were used in this experiment with three replications in randomised complete block design (RCBD). The treatments were $\mathrm{T}_{1}$ : control, $\mathrm{T}_{2}$ : Alcaligenes sp. AZ9, $\mathrm{T}_{3}$ : rock phosphate enriched compost (RPEC) - 0.5 tons ha ${ }^{-1}, \mathrm{~T}_{4}$ : humic acid (HA) - $24.7 \mathrm{~kg} \mathrm{ha}^{-1}, \mathrm{~T}_{5}$ : biochar - 0.5 tons ha ${ }^{-1}, \mathrm{~T}_{6}$ : RPEC $(0.5$ tons $\left.\mathrm{ha}^{-1}\right)+\mathrm{AZ9}, \mathrm{T}_{7}$ : HA $\left(24.7 \mathrm{~kg} \mathrm{ha}^{-1}\right)+\mathrm{AZ} 9, \mathrm{~T}_{8}$ : biochar $(0.5$ tons ha $\left.{ }^{-1}\right)+\mathrm{AZ9}, \mathrm{T}_{9}$ : RPEC $\left(0.5\right.$ tons ha $\left.{ }^{-1}\right)+\mathrm{HA}\left(24.7 \mathrm{~kg} \mathrm{ha}^{-1}\right)+$ Biochar $\left(0.5\right.$ tons ha $\left.{ }^{-1}\right)$ and T10: RPEC $\left(0.5\right.$ tons ha $\left.{ }^{-1}\right)+$ HA $(24.7$ $\left.\mathrm{kg} \mathrm{ha}^{-1}\right)+$ Biochar $\left(0.5\right.$ tons ha $\left.{ }^{-1}\right)+$ AZ9. The recommended dose of NPK 175, 160, and $125 \mathrm{~kg} \mathrm{ha}^{-1}$ respectively were applied in terms of urea, diammonium phasphate and sulphate of potash respectively. Full $\mathrm{P}$ and $\mathrm{K}$ fertilisers were applied as basal doses at the time of field preparation. $\mathrm{N}$ fertiliser was split into two equal doses and applied at the time of maize sowing and one month after germination. Field was irrigated on demand with available source of good quality underground water. Crop data were collected in terms of growth, yield and nutrients concentration in grains upon crop harvest. After crop harvest, soil samples were analysed for various soil biological characteristics as discussed below.

\section{Growth and yield observation}

The growth and yield attributes in terms of plant height, shoot fresh and dry biomass, 1000-grains weight, grain yield and stover yield was determined. Plant height was measured at maturity with the measuring tape. Fresh and dry biomasses were recorded after the harvesting of maize. The 1000-grains were counted and 
weighted to estimate the data of 1000-grains weight. The grain and stover yield were estimated from each treatment and data was represented in tons $\mathrm{ha}^{-1}$.

\section{Quality parameters of grains}

For nutrient analysis, grain samples were digested as described by Wolf (1982). According to this method, oven dried ground grains $(0.1 \mathrm{~g})$ were taken in digestion tubes along with $\mathrm{H}_{2} \mathrm{SO}_{4}(2$ $\mathrm{mL}$ ) in digestion tubes and kept for $24 \mathrm{~h}$ at $25^{\circ} \mathrm{C}$. On next day, $\mathrm{H}_{2} \mathrm{O}_{2}(1 \mathrm{~mL})$ was added in tubes and heated up to $350^{\circ} \mathrm{C}$ for $30 \mathrm{~min}$ on the hot plate. Further $\mathrm{H}_{2} \mathrm{O}_{2}(1 \mathrm{~mL})$ was also added in tubes and heated for $20 \mathrm{~min}$. These steps were repeated for colourless appearance of digestion material. After that, distal water was added in filtered extract up to $50 \mathrm{~mL}$. N content of filtrate was determined by using the Kjeldahl method (Jackson, 1958). The P and K contents in extracts were determined by following the methods of Ashraf et al. (1992) and Chapman and Pratt (1961), respectively.

\section{Soil analysis after harvest}

After crop harvesting, soil samples were collected and analysed for colony forming units (CFU), MBC, SOC and saturation percentage. Bacterial CFU was estimated by using standard serial dilution and pour plate method (Nichols et al., 1997). MBC was estimated by the chloroform fumigation and extraction method (Jenkinson and Ladd, 1981). SOC was estimated by adopting the method of Khalil and Osborne (2018). The saturation percentage of soil sample was calculated by following the formula reported by (Sarfraz et al., 2017).

\section{Statistical analysis}

The field experiment was conducted using RCBD. Data regarding growth, yield, macronutrient parameters of maize attributes and soil parameters after harvesting were analysed statistically using software 'Statistix $8.1^{\circledR}$ ' for analysis of variance (ANOVA) and means were compared by using least significant difference test (Steel et al., 2007).

\section{Results}

A field experiment was conducted to evaluate the effectiveness of organic amendments viz. RPEC, biochar and humic acid with/ without Alcaligenes sp. AZ9 to improve maize growth, yield and nutrients concentration in grains. Their investigations are being discussed as follows.

\section{Plant growth}

Here, we reported maize growth in terms of plant height, shoot fresh and dry biomass (Table 1). Variable responses were obtained from applied treatments. Although a significant increase in plant growth attributes was observed with sole application of organic amendments along with Alcaligenes sp. AZ9 while, their combined application was more capable to promote plant growth. The maximum increase in growth attributes was observed with the combined application of Alcaligenes sp. AZ9 and organic amendment viz. RPEC, biochar and humic acid. This treatment showed an increase up to 14,30 , and $30 \%$ in plant height, shoot fresh and dry biomass as compared to absolute control.

\section{Maize yield}

The effect of sole and combined application of organic amendments with/without Alcaligenes sp. AZ9 on yield attributes is shown in Table 2. Yield attributes i.e. 1000-grain weight, grain yield and stover yield was significantly promoted over absolute control. The combined application of organic amendments viz. RPEC, biochar and humic acid with Alcaligenes sp. AZ9 reported a better increase in yield attributes. The maximum increase in 1000 -grain weight up to $10 \%$, grain yield up to $31 \%$, and stover yield up to $34 \%$ were observed with combined application of RPEC, biochar, humic acid and Alcaligenes sp. AZ9 as compared to control.

\section{NPK concentration in grain}

The quality parameters like NPK concentration due to organic

Table 1. Impact of combined application of enriched compost, biochar, humic acid and plant growth promoting rhizobacteria on growth and yield parameters of maize crop in a field trial.

\begin{tabular}{|c|c|c|c|}
\hline Treatments & Plant height (cm) & Fresh biomass (tons ha-1) & Dry biomass (tons ha-1) \\
\hline $\mathrm{T}_{1}=$ Control & $187^{\mathrm{d}}$ & $54.5^{\mathrm{f}}$ & $17.9^{\mathrm{e}}$ \\
\hline $\mathrm{T}_{2}=$ Alcaligenes sp. AZ9 & $191^{\text {cd }}(2)$ & $58.8 \mathrm{ef}(8)$ & $19.7^{\text {cde }}(10)$ \\
\hline $\mathrm{T}_{3}=$ Rock phosphate enriched compost & $196^{\mathrm{bcd}}(5)$ & $61.4^{\mathrm{de}}(13)$ & $19.1^{\text {de }}(7)$ \\
\hline $\mathrm{T}_{4}=$ Humic acid & $198^{\mathrm{bc}}(6)$ & $62.1^{\text {cde }}(14)$ & $19.6^{\text {cde }}(10)$ \\
\hline $\mathrm{T}_{5}=$ Biochar & $199^{\mathrm{bc}}(6)$ & $64.7^{\text {bcd }}(19)$ & $20.6^{\text {bcd }}(15)$ \\
\hline $\mathrm{T}_{6}=\mathrm{RPEC}+$ Alcaligenes sp. AZ9 & $202^{\mathrm{b}}(8)$ & $64.9^{\mathrm{bcd}}(19)$ & $22.0^{\mathrm{abc}}(23)$ \\
\hline $\mathrm{T}_{7}=$ Humic acid + Alcaligenes sp. AZ9 & $200^{\mathrm{bc}}(7)$ & $66.7^{\mathrm{abc}}(22)$ & $22.1^{\mathrm{abc}}(24)$ \\
\hline $\mathrm{T}_{8}=$ Biochar + Alcaligenes sp. AZ9 & $204^{\mathrm{b}}(9)$ & $64.6^{\text {bcd }}(18)$ & $22.3^{\mathrm{abc}}(25)$ \\
\hline $\mathrm{T}_{9}=\mathrm{RPEC}+$ Humic acid + Biochar & $205^{\mathrm{ab}}(9)$ & $69.0^{\mathrm{ab}}(27)$ & $23.1^{\mathrm{ab}}(29)$ \\
\hline $\mathrm{T}_{10}=\mathrm{RPEC}+$ Humic acid + Biochar + Alcaligenes sp. AZ9 & $213^{\mathrm{a}}(14)$ & $70.7^{\mathrm{a}}(30)$ & $23.3^{\mathrm{a}}(30)$ \\
\hline $\mathrm{LSD}(\mathrm{P} \leq 0.05)$ & 9.5384 & 4.6788 & 2.6664 \\
\hline CV & 2.79 & 4.28 & 7.41 \\
\hline
\end{tabular}

Data are shown as mean of three replicates; means followed by the same letter(s) within the column are not significantly different according to least significance difference (LSD) test at $\mathrm{P} \leq 0.05$. 
amendments with/ without Alcaligenes sp. AZ9 in grain were nonsignificant to each other however, they were significantly different as compared to absolute control (Table 3). Results revealed that $\mathrm{N}$, $\mathrm{P}$ and $\mathrm{K}$ accumulation in grain due to applied treatments ranged from 2.4 to $2.6 \%, 0.5$ to $0.6 \%$ and 2.7 to $3.0 \%$, respectively. The combined application of RPEC, biochar and humic acid with/ without Alcaligenes sp. AZ9 showed a maximum increase in $\mathrm{N}$ and $\mathrm{P}$ and were non-significant to each other. The maximum increase in $\mathrm{K}$ concentration (up to $12 \%$ ) was demonstrated by the combined application of RPEC, biochar and humic acid with Alcaligenes sp. AZ9 that was non-significant with their combined application without Alcaligenes sp. AZ9.

\section{Soil attributes}

Soil attributes in terms of bacterial population, SOC, MBC and saturation percentage were observed after maize harvesting as demonstrated in Figures 1-4. The application of organic amendments along with/without Alcaligenes sp. AZ9 causes a significant increase in these attributes as compared to their sole application.
The combined application of RPEC, biochar and humic acid along with Alcaligenes sp. AZ9 showed a maximum increase in bacterial population up to $60 \%$, SOC up to $29 \%$, MBC $22 \%$, and saturation percentage up to $14 \%$ over absolute control.

\section{Discussion}

The replenishment of nutrients reserve after crop harvest is necessary to improve soil productivity of farming systems. The nutrients can be renewed through the combined application of PGPR and organic amendments. Soil microbial population, MBC and SOC along with maize growth and yield were increased in the present experiment due to use of organic amendments along with Alcaligenes sp. AZ9 in the soil.

Soil microbial and biochemical properties are very reactive to small changes in management practices and can be used in estimating the effects of use of organic amendments. Microbial population in the soil is involved in organic matter decomposition and trans-

Table 2. Impact of combined application of enriched compost, biochar, humic acid and plant growth promoting rhizobacteria on growth and yield parameters of maize crop in a field trial.

\begin{tabular}{|c|c|c|c|}
\hline Treatments & 1000 grain weight (g) & Grain yield (tons ha' ${ }^{-1}$ ) & Stover yield (tons ha-1) \\
\hline $\mathrm{T}_{1}=$ Control & $350.8^{\mathrm{d}}$ & $9.0^{\mathrm{e}}$ & $3.1^{\mathrm{f}}$ \\
\hline $\mathrm{T}_{2}=$ Alcaligenes sp. AZ9 & $355.0^{\mathrm{d}}(1)$ & $9.1^{\mathrm{de}}(1)$ & $3.4^{\mathrm{de}}(10)$ \\
\hline $\mathrm{T}_{3}=$ Rock phosphate enriched compost & $356.2^{\mathrm{d}}(2)$ & $9.6^{\text {cde }}(6)$ & $3.4^{\text {de }}(10)$ \\
\hline $\mathrm{T}_{4}=$ Humic acid & $366.3^{\mathrm{c}}(4)$ & $9.9^{\text {cde }}(9)$ & $3.2^{\mathrm{ef}}(5)$ \\
\hline $\mathrm{T}_{5}=$ Biochar & $365.4^{\mathrm{c}}(4)$ & $9.7^{\text {cde }}(8)$ & $3.6^{\mathrm{cd}}(16)$ \\
\hline $\mathrm{T}_{6}=\mathrm{RPEC}+$ Alcaligenes sp. AZ9 & $375.7^{\mathrm{b}}(7)$ & $10.3^{\mathrm{bc}}(14)$ & $3.6^{\text {cd }}(17)$ \\
\hline $\mathrm{T}_{7}=$ Humic acid + Alcaligenes sp. AZ9 & $374.4^{\mathrm{b}}(7)$ & $10.1^{\text {cd }}(11)$ & $3.7^{\mathrm{c}}(20)$ \\
\hline $\mathrm{T}_{8}=$ Biochar + Alcaligenes sp. AZ9 & $375.6^{\mathrm{b}}(7)$ & $10.6^{\mathrm{bc}}(17)$ & $3.7^{\mathrm{bc}}(21)$ \\
\hline $\mathrm{T}_{9}=$ RPEC + Humic acid + Biochar & $378.0^{\mathrm{b}}(8)$ & $11.1^{\mathrm{ab}}(23)$ & $3.9^{\mathrm{ab}}(28)$ \\
\hline $\mathrm{T}_{10}=\mathrm{RPEC}+$ Humic acid + Biochar + Alcaligenes sp. AZ9 & $384.8^{\mathrm{a}}(10)$ & $11.8^{\mathrm{a}}(31)$ & $4.1^{\mathrm{a}}(34)$ \\
\hline LSD $(\mathrm{P} \leq 0.05)$ & 6.6677 & 0.9983 & 0.2387 \\
\hline CV & 1.06 & 5.75 & 3.91 \\
\hline
\end{tabular}

Data are shown as mean of three replicates; means followed by the same letter(s) within the column are not significantly different according to least significance difference (LSD) test at P $\leq 0.05$.

Table 3. Impact of combined application of enriched compost, biochar, humic acid and plant growth promoting rhizobacteria on quality parameters of maize and bacterial population after harvesting the crop in a field trial.

\begin{tabular}{|c|c|c|c|}
\hline Treatments & $\mathrm{N}$ in grain (\%) & $\mathrm{P}$ in grain $(\%)$ & $\mathrm{K}$ in grain (\%) \\
\hline $\mathrm{T}_{1}=$ Control & $2.4^{\mathrm{f}}$ & $0.5^{\mathrm{d}}$ & $2.7^{\mathrm{d}}$ \\
\hline $\mathrm{T}_{2}=$ Alcaligenes sp. AZ9 & $2.4^{\mathrm{ef}}(2)$ & $0.5^{\text {cd }}(3)$ & $2.7^{\mathrm{cd}}(.4)$ \\
\hline $\mathrm{T}_{3}=$ Rock phosphate enriched compost & $2.4^{\mathrm{ef}}(2)$ & $0.6^{\mathrm{cd}}(4)$ & $2.7^{\mathrm{cd}}(1)$ \\
\hline $\mathrm{T}_{4}=$ Humic acid & $2.5^{\mathrm{cd}}(6)$ & $0.6^{\mathrm{cd}}(4)$ & $2.7^{\mathrm{cd}}(1)$ \\
\hline $\mathrm{T}_{5}=$ Biochar & $2.5^{\mathrm{de}}(4)$ & $0.6^{\mathrm{bc}}(7)$ & $2.7^{\mathrm{cd}}(1)$ \\
\hline $\mathrm{T}_{6}=\mathrm{RPEC}+$ Alcaligenes sp. AZ9 & $2.5^{\mathrm{bc}}(7)$ & $0.6^{\mathrm{bc}}(6)$ & $2.8^{\mathrm{bcd}}(4)$ \\
\hline $\mathrm{T}_{7}=$ Humic acid + Alcaligenes sp. AZ9 & $2.6^{\mathrm{abc}}(8)$ & $0.6^{\mathrm{bc}}(7)$ & $2.8^{\mathrm{bc}}(4)$ \\
\hline $\mathrm{T}_{8}=$ Biochar + Alcaligenes sp. AZ9 & $2.6^{\mathrm{abc}}(9)$ & $0.6^{\mathrm{abc}}(8)$ & $2.8^{\mathrm{bcd}}(4)$ \\
\hline $\mathrm{T}_{9}=\mathrm{RPEC}+$ Humic acid + Biochar & $2.6^{\mathrm{ab}}(9)$ & $0.6^{\mathrm{ab}}(9)$ & $2.9^{\mathrm{ab}}(8)$ \\
\hline $\mathrm{T}_{10}=\mathrm{RPEC}+$ Humic acid + Biochar + Alcaligenes sp. AZ9 & $2.6^{\mathrm{a}}(11)$ & $0.6^{\mathrm{a}}(12)$ & $3.0^{\mathrm{a}}(12)$ \\
\hline LSD $(\mathrm{P} \leq 0.05)$ & 0.0713 & 0.0247 & 0.1277 \\
\hline CV & 1.65 & 2.56 & 2.66 \\
\hline
\end{tabular}

Data are shown as mean of three replicates; means followed by the same letter(s) within the column are not significantly different according to least significance difference (LSD) test at P $\leq 0.05$. 
formation and cycling of minerals (Paul, 2016). In the present study, the combined application of organic amendments along with Alcaligenes sp. AZ9 improved soil attributes in terms of soil microbial population, $\mathrm{MBC}, \mathrm{SOC}$ and saturation percentage that could be due to the more labile fraction of organic matter in upper soil layers. Organic amendments are slowly decomposed and sustain microbial biomass population through the continuous release of nutrients (Murphy et al., 2007; Tejada et al., 2009). Microbial population could play a key role in enzymatic activities, mineralisation of soil organic carbon, availability of nutrients and substantially changes the bacterial community structure (Hartmann et al., 2015). There is a strong correlation between soil fertility and SOC content as a result of enhanced microbial diversity (Chakraborty et al., 2011). Previously, long term experiments have been demonstrated that use of organic amendments improve soil biological properties such as microbial population, MBC and enzymatic activity, and water holding capacity (Ros et al., 2006; Tejada et al., 2009; Schulz et al., 2014; Chen et al., 2018).

Among evaluated organic amendments in the current study, biochar application in presence of Alcaligenes sp. AZ9 showed better ability to promote plant growth and yield attributes. Previously, Saxena et al. (2013) reported increased growth of French bean due to the application of biochar and Bacillus sp. Biochar possesses a porous structure that may promote the survival and activity of Alcaligenes sp. AZ9. Biochar-amended soil represented larger rhizosphere zones of plants (Prendergast-Miller et al., 2014). It improves root traits like root extension, biomass, volume and surface area that alleviate plant nutrients, water deficiency and also maximise biomass accumulation (Xiang et al., 2017). The organic amendment had the ability to improve nutrients availability and their retention in soil that improved the crop growth and yield as we observed in the current study. Increase in plant growth and yield were more with the combined application of organic amendments and Alcaligenes sp. AZ9. Bacterial strains mobilised the nutrient availability through acidification and chelation that ensured nutrient availability (Perez-Montano et al., 2014). The organic amendments along with bacterial strains could result in the production of more organic acids, carbon sequestration, enhanced the storing of slow release of nutrients for mineralisation and improve soil physical and chemical fertility (Chakraborty et al., 2011; Chen et al., 2018). Application of RPEC, biochar and humic acid individually or together when combined with Alcaligenes sp. AZ9 significantly enhanced nutrient accumulation as indicated by increased nutrient content in maize grains. It might be due to increase in $\mathrm{MBC}, \mathrm{SOC}$ and a microbial population that improved $\mathrm{N}, \mathrm{P}$, and $\mathrm{K}$ availability.

Alcaligenes sp. AZ9 had the ability to reduce induced ethylene production through its ACC-deaminase enzyme as well as

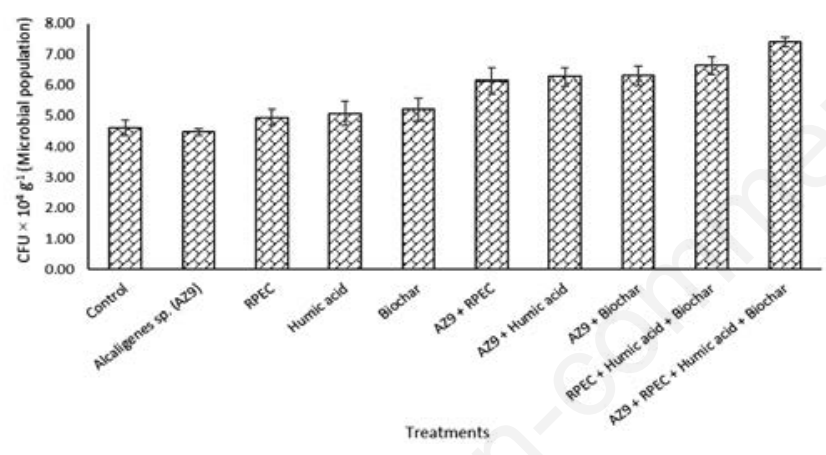

Figure 1. Impact of integrated application of enriched compost, biochar and humic acid and Alcaligenes sp. AZ9 on soil microbial population.

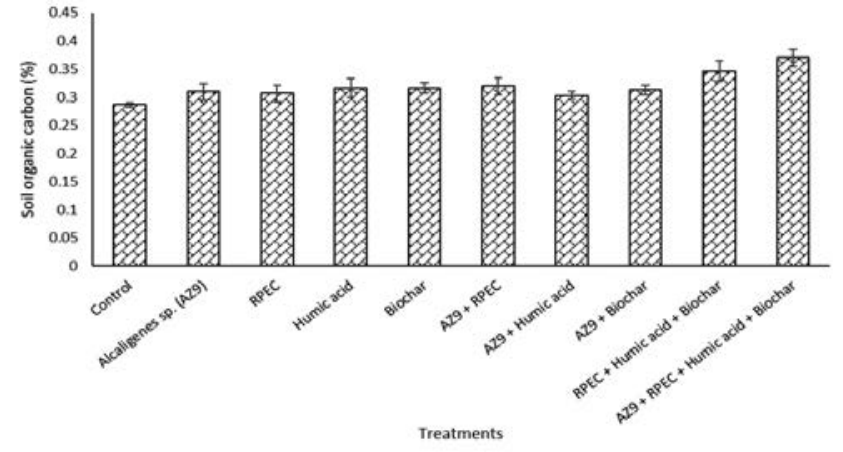

Figure 2. Impact of integrated application of enriched compost, biochar and humic acid and Alcaligenes sp. AZ9 on soil organic carbon $(\%)$.

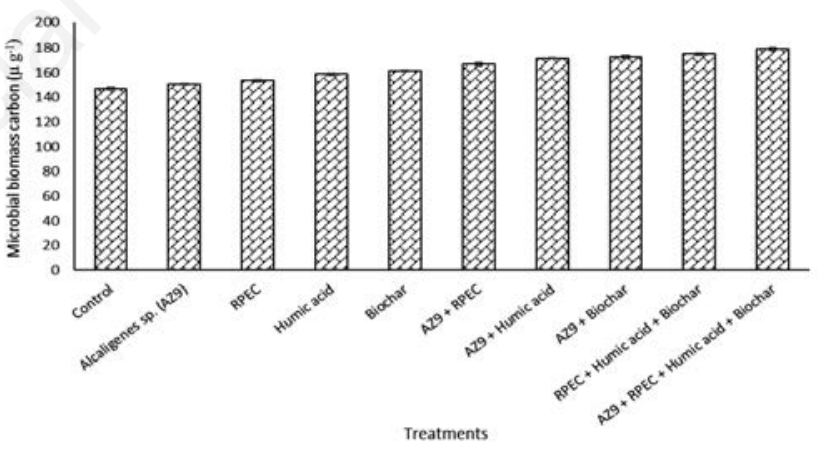

Figure 3. Impact of integrated application of enriched compost, biochar and humic acid and Alcaligenes sp. AZ9 on microbial biomass carbon.

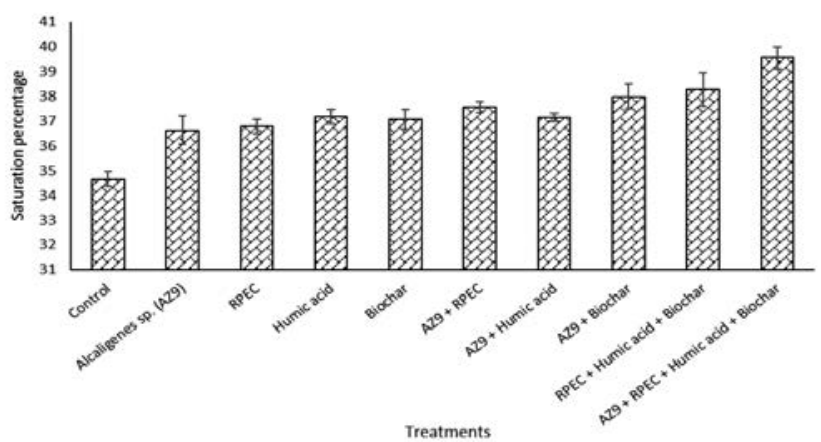

Figure 4. Impact of integrated application of enriched compost, biochar and humic acid and Alcaligenes sp. AZ9 on soil saturation percentage. 
exopolysaccharides production. Moreover, the strain had P \& Zn solubilisation, production of siderophores and IAA, which might be the reason for the improvement in plant growth and yield in a better way (Hussain et al., unpublished). Bacteria with such traits are very effective for better growth, nutrients use efficiency and grain yield (Mumtaz et al., 2017, 2018). PGPR have the ability to produce ammonia, which is utilised by the plant as a source of $\mathrm{N}$ (Zafar-ul-Hye et al., 2013). Replenishment of organic matter derived from microbial biomass and plants is critical to ensure long-term soil fertility and sustainable crop production. Application of organic amendments individually or together, combined with Alcaligenes sp. AZ9 could decrease chemical fertilisers requirement for crop production. It will also be effective to use organic resources as nutrient sources to fulfill biomass production.

\section{Conclusions}

The current study concluded that the combined application of organic amendments and Alcaligenes sp. AZ9 promoted soil biological attributes, maize growth and productivity more efficiently. It may also lead to contribute towards healthier soil, plant, and grains. It may reduce the dependence on chemical fertilisers, which are too costly and hazardous for the environment as well. The farmer's community can get maximum profit from their limited resources by adopting this environmental friendly technique.

\section{References}

Ahemad M, Kibret M, 2014. Mechanisms and applications of plant growth promoting rhizobacteria: current perspective. J. King Saud. Univ. Sci. 26:1-20.

Ahmad M, Zahir ZA, Nadeem SM, Nazli F, Jamil M, Khalid M, 2013. Field evaluation of Rhizobium and Pseudomonas strains to improve growth, nodulation and yield of mung bean under salt-affected conditions. Soil Environ. 32:158-66.

Alluvione F, Fiorentino N, Bertora C, Zavattaro L, Fagnano M, Chiarandà FQ, Grignani C, 2013. Short-term crop and soil response to $\mathrm{C}$-friendly strategies in two contrasting environments. Eur. J. Agron. 45:114-23.

Alori ET, Glick BR, Babalola OO, 2017. Microbial phosphorus solubilization and its potential for use in sustainable agriculture. Front. Microbiol. 8:971.

Arshad M, Ashraf MY, Ahamad M, Zaman F, 2007. Morphogenetic variability potential of Cenchrus ciliaris L., from Cholistan desert, Pakistan. Pak. J. Bot. 39:1481-8.

Ashraf MY, Khan AH, Azmi AR, 1992. Cell membrane stability and its relation with some physiological process in wheat. Acta Agron. Hung. 41:182-91.

Bertrand M, Barot S, Blouin M, Whalen J, de Oliveira T, RogerEstrade J, 2015. Earthworm services for cropping systems, a review. Agron. Sustain. Dev. 35:553-67.

Caravaca F, Alguacil MM, Azcón R, Parladé J, Torres P, Roldán A, 2005. Establishment of two ectomycorrhizal shrub species in a semiarid site after in situ amendment with sugar beet, rock phosphate and Aspergillus niger. Microb. Ecol. 49:73-82.

Chakraborty A, Chakrabarti K, Chakraborty A, Ghosh S, 2011. Effect of long-term fertilizers and manure application on microbial biomass and microbial activity of a tropical agricultural soil. Biol. Fertil. Soils 47:227-33.
Chapman HD, Pratt PF, 1961. Method of analysis for soils, plants and waters. University of California Division Agriculture Sciences, Berkeley, CA, USA.

Chappell A, Webb NP, Leys JF, Waters CM, Orgill S, Eyres MJ, 2019. Minimising soil organic carbon erosion by wind is critical for land degradation neutrality. Environ. Sci. Policy 93:43-52.

Chen Y, Camps-Arbestain M, Shen Q, Singh B, Cayuela ML, 2018. The long-term role of organic amendments in building soil nutrient fertility: a meta-analysis and review. Nutr. Cycl. Agroecosys. 111:103-25.

Chen YP, Rekha PD, Arun AB, Shen FT, Lai WA, Young CC, 2006. Phosphate solubilizing bacteria from subtropical soil and their tricalcium phosphate solubilizing abilities. Appl. Soil Ecol. 34:33-41.

Ditta A, Arshad M, Zahir ZA, Jamil A, 2015. Comparative efficacy of rock phosphate enriched organic fertilizer vs. mineral phosphatic fertilizer for nodulation, growth and yield of lentil. Int. J. Agric. Biol. 17:589-95.

Hartmann M, Frey B, Mayer J, Mäder P, Widmer F, 2015. Distinct soil microbial diversity under long-term organic and conventional farming. ISME J. 9:1177-94.

Hussain A, Arshad M, Zahir ZA, Asghar M, 2015. Prospects of zinc solubilizing bacteria for enhancing growth of maize. Pak. J. Agric. Sci. 52:915-22.

Jackson ML, 1958. Soil chemical analysis. Verlag: Prentice Hall, Inc., Englewood Cliffs, New York, USA.

Jenkinson DS, Ladd JN, 1981. Microbial biomass in soil: measurement and turnover. In: E.A. Paul, J.N. Ladd (ed.) Soil biochemistry, New York, USA. pp 415-471.

Khalil MI, Osborne BA, 2018. Improving estimates of soil organic carbon (SOC) stocks and their long-term temporal changes in agricultural soils in Ireland. Geoderma 322:172-83.

Khan K, Pankaj U, Verma SK, Gupta AK, Singh RP, Verma RK, 2015. Bio-inoculants and vermicompost influence on yield, quality of Andrographis paniculata, and soil properties. Ind. Crops Prod. 70:404-9.

Lal R, Hansen DO, Uphoff N, 2010. Food security and environmental quality in the developing world. CRC Press, Boca Raton, FL, USA.

Mahmoodabadi M, Ahmadbeygi B, 2013. Dry and water-stable aggregates in different cultivation systems of arid region soils. Arab. J. Geosci. 6:2997-3002.

Malik MA, Marschner P, Khan KS, 2012. Addition of organic and inorganic P sources to soil - Effects on P pools and microorganisms. Soil Biol. Biochem. 49:106-13.

Mittal P, Kamle M, Sharma S, Choudhary P, Rao DP, Kumar P, 2017. Plant growth-promoting rhizobacteria (PGPR): mechanism, role in crop improvement and sustainable agriculture. In: H.B. Singh, B.K. Sarma, C. Keswani (ed.), Advances in PGPR Research, CABI, Nosworthy, Wallingford Oxfordshire, UK, pp 386-397.

Moharana PC, Meena MD, Biswas DR, 2018. Role of phosphatesolubilizing microbes in the enhancement of fertilizer value of rock phosphate through composting technology. In: V.S. Meena (ed.), Role of rhizospheric microbes in soil. Springer, Singapore, pp 167-202.

Mumtaz MZ, Ahmad M, Jamil M, Asad SA, Hafeez F, 2018. Bacillus strains as potential alternate for zinc biofortification of maize grains. Int. J. Agric. Biol. 20:1779-86.

Mumtaz MZ, Ahmad M, Jamil M, Hussain T, 2017. Zinc solubilizing Bacillus spp. potential candidates for biofortification in maize. Microbiol. Res. 202:51-60.

Murphy D.V., Stockdale E.A., Brookes P.C., Goulding K.W.T., 
2007. Impact of microorganisms on chemical transformation in soil. In: L.K. Abbott, D.V. Murphy (ed.), Soil biological fertility - A key to sustainable land use in agriculture, Springer, pp 37-59.

Nichols TD, Wolf DC, Rogers HB, Beyrouty CA, Reynolds CM, 1997. Rhizosphere microbial populations in contaminated soils. Water Air Soil Pollut. 95:165-78.

Onwosi CO, Igbokwe VC, Odimba JN, Eke IE, Nwankwoala MO, Iroh IN, Ezeogu LI, 2017. Composting technology in waste stabilization: on the methods, challenges and future prospects. J. Environ. Manage. 190:140-57.

Paul EA, 2016. The nature and dynamics of soil organic matter: plant inputs, microbial transformations, and organic matter stabilization. Soil Biol. Biochem. 98:109-26.

Perez-Montano F, Alías-Villegas C, Bellogín RA, Del CP, Espuny MR, Jiménez-Guerrero I, López-Baena FJ, Ollero FJ, Cubo T, 2014. Plant growth promotion in cereal and leguminous agricultural important plants: from microorganism capacities to crop production. Microbiol. Res. 169:325-36.

Prendergast-Miller M, Duvall M, Sohi S, 2014. Biochar-root interactions are mediated by biochar nutrient content and impacts on soil nutrient availability. Eur. J. Soil Sci. 65:173-85.

Randolph P, Bansode RR, Hassan OA, Rehrah D, Ravella R, Reddy MR, Watts DW, Novak JM, Ahmedna M, 2017. Effect of biochars produced from solid organic municipal waste on soil quality parameters. J. Environ. Manage.192:271-80.

Ros M, Klammer S, Knapp B, Aichberger K, Insam H, 2006. Long-term effects of compost amendment of soil on functional and structural diversity and microbial activity. Soil Use Manage. 22:209-18.

Sarfraz R, Shakoor A, Abdullah M, Arooj A, Hussain A, Xing S, 2017. Impact of combined application of biochar and nitrogen fertilizers on maize growth and nitrogen recovery in alkaline calcareous soil. Soil Sci. Plant Nutr. 63:488-98.

Saxena J, Rana G, Pandey M, 2013. Impact of addition of biochar along with Bacillus sp. on growth and yield of French beans. Sci. Hort. 162:351-6.

Schulz H, Dunst G, Glaser B, 2014. No effect level of co-composted biochar on plant growth and soil properties in a greenhouse experiment. Agronomy 4:34-51.

Scotti R, Bonanomi G, Scelza R, Zoina A, Rao MA, 2015. Organic amendments as sustainable tool to recovery fertility in intensive agricultural systems. J. Soil Sci. Plant Nutr. 15:333-52.

Shahzad SM, Arif MS, Riaz M, Ashraf M, Iqbal Z, 2013. PGPR with varied ACC-deaminase activity induced different growth and yield response in maize (Zea mays L.) under fertilized conditions. Eur. J. Soil Biol. 57:27-34.

Steel RGD, Torrie JH, Dickey DA, 2007. Principles and procedures of statistics, a biometrical approach, $3^{\text {rd }}$ Ed. McGraw Hill Book Co., New York, NY, USA.

Tejada M, Hernandez MT, Garcia C, 2009. Soil restoration using composted plant residues: effects on soil properties. Soil Till. Res. 102:109-17.

Vessey JK, Buss TJ, 2003. Bacillus cereus UW85 inoculation effects on growth, nodulation and $\mathrm{N}$ accumulation in grain legumes: controlled-environment studies. Can. J. Plant Sci. 82:282-90.

Wolf B, 1982. The comprehensive system of leaf analysis and its use for diagnosing crop nutrient status. Commun. Soil Sci. Plant Anal. 13:1035-59.

Xiang Y, Deng Q, Duan H, Guo Y, 2017. Effects of biochar application on root traits: a meta-analysis. GCB Bioenergy 9:1563-72.

Zafar-ul-Hye M, Ahmad M, Shahzad SM, 2013. Synergistic effect of rhizobia and plant growth promoting rhizobacteria on the growth and nodulation of lentil seedlings under axenic conditions. Soil Environ. 32:79-86. 